\title{
Photometric analysis applied in determining facial type
}

\author{
Luciana Flaquer Martins', Julio Wilson Vigorito²
}

Introduction: In orthodontics, determining the facial type is a key element in the prescription of a correct diagnosis. In the early days of our specialty, observation and measurement of craniofacial structures were done directly on the face, in photographs or plaster casts. With the development of radiographic methods, cephalometric analysis replaced the direct facial analysis. Seeking to validate the analysis of facial soft tissues, this work compares two different methods used to determining the facial types, the anthropometric and the cephalometric methods. Methods: The sample consisted of sixty-four Brazilian individuals, adults, Caucasian, of both genders, who agreed to participate in this research. All individuals had lateral cephalograms and facial frontal photographs. The facial types were determined by the Vert Index (cephalometric) and the Facial Index (photographs). Results: The agreement analysis (Kappa), made for both types of analysis, found an agreement of 76.5\%. Conclusions: We concluded that the Facial Index can be used as an adjunct to orthodontic diagnosis, or as an alternative method for pre-selection of a sample, avoiding that research subjects have to undergo unnecessary tests.

Keywords: Diagnostic techniques and procedures. Orthodontics. Anthropometry.

Introdução: em Ortodontia, a determinação do tipo facial é um elemento-chave na prescrição de um diagnóstico correto. Nos primórdios de nossa especialidade, a observação e a medição das estruturas craniofaciais eram feitas diretamente na face, em fotografias ou em modelos de gesso. Com o desenvolvimento dos métodos radiográficos, a análise cefalométrica foi substituindo a análise facial direta. Visando legitimar o estudo dos tecidos moles faciais, esse trabalho comparou a determinação do tipo facial pelos métodos antropométrico e cefalométrico. Métodos: a amostra constou de sessenta e quatro indivíduos brasileiros, adultos, leucodermas, de ambos os sexos, que aceitaram participar da pesquisa. De todos os indivíduos da amostra foram feitas telerradiografias laterais e fotografias faciais frontais, e os tipos faciais determinados pelo Índice Vert (cefalometricamente) e pelo Índice Facial (fotografias). Resultados: pela análise de concordância (Kappa), feita para os dois tipos de análise, encontramos uma concordância de 76,5\%. Conclusões: foi possível considerar que o Índice Facial pode ser utilizado como um coadjuvante do diagnóstico ortodôntico, ou como método alternativo para pré-seleção de uma amostra, evitando que os sujeitos de pesquisas sejam submetidos a exames desnecessários.

Palavras-chave: Técnicas de diagnóstico e procedimentos. Ortodontia. Antropometria.

\section{INTRODUCTION}

For countless generations man observed and measured the physical characteristics of the human body. ${ }^{1,2,3}$

During the Renaissance period, Leonardo da Vinci made a number of studies on the proportions and indexes of the human body, characterizing the anatomi-

» Patients displayed in this article previously approved the use of their facial and intraoral photographs.

${ }^{1} \mathrm{PhD}$ in Orthodontics, FOUSP. Head Professor, Specialization Course in Orthodontics, CIODONTO - Santo André Unity.

${ }^{2} \mathrm{PhD}$ in Orthodontics, USP. Professor of Orthodontics, FOUSP. cal structures. Among these studies, we can find drawings of different facial types and characteristics, which even today can be found in our society ${ }^{4}$ (Fig 1).

Angle ${ }^{1}$, in 1899, noted that for the orthodontist to be capable to correctly diagnose malocclusions, he should also be familiar with the normal or ideal occlusion,

How to cite this article: Martins LF, Vigorito JW. Photometric analysis applied in determining facial type. Dental Press J Orthod. 2012 Sept-Oct;17(5):71-5.

Submitted: June 11, 2010 - Revised and accepted: August 06, 2012.

» The authors report no commercial, proprietary or financial interest in the products or companies described in this article.

Contact address: Luciana Flaquer Martins

Rua das Caneleiras, 1074 - Santo André/SP, Brazil - Zip code: 09.090-050

E-mail: luflaquer@uol.com.br 


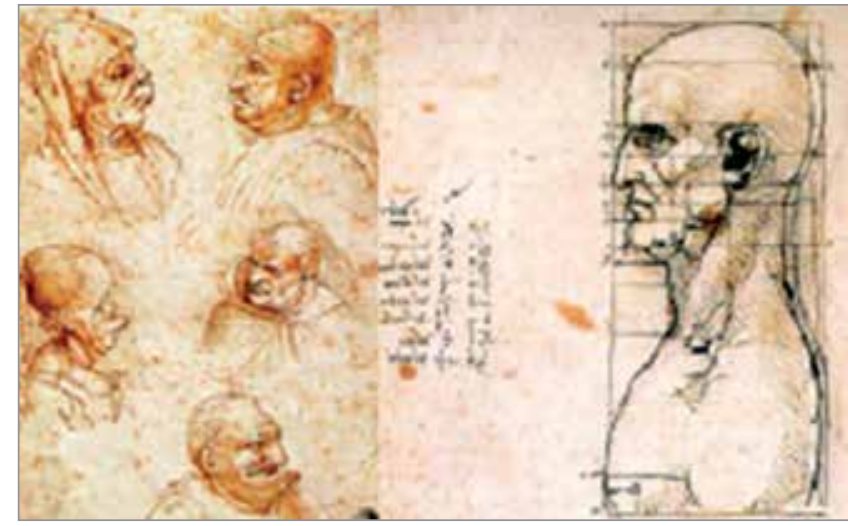

Figure 1 - Drawings of facial features described by da Vinci in the fifteenth century.

observe normal facial lines, taking into consideration the norm, straight profile like that of Apollo Belvedere.

However, in 1907, Angle ${ }^{2}$ noted that the goal of a straight profile as that of Apollo at the end of orthodontic treatment was a result unlikely to be achieved, since there were many different facial patterns in different human groups. Thus, he emphasized that the role of the orthodontist was to detect whether facial structures were in harmony, and that this should be in accordance with well-positioned teeth and a balanced occlusion.

The best way to develop the ability to evaluate faces is to observe them several times. With this practice the orthodontist develops the ability to determine the facial characteristics of each subject. Herzberg, ${ }^{4}$ pointed out that standardized photographs would be the best method, because only with them it would be possible to evaluate in detail the measures and proportions, even for those who were still starting in the practice of facial evaluation.

Montangu ${ }^{5}$ characterized the anthropometry as a branch of anthropology where individuals are categorized by measurements made by means of acquired images (photographs or radiographs) or directly on soft tissue or bone. Among other measures, he regarded the proportions of the human body, he also has described the Facial Index (where the facial height and width are correlated) which can characterize three facial types:

» Mesoprosopic (facial height and width in the same proportion).
» Euriprosopic (facial width greater than height).

» Leptoprosopic (facial height greater than width).

When there is a comparison between the reliability of photometric and anthropometric methods for evaluation of facial features, a large share of the measures and indexes are comparable. ${ }^{8}$ In the comparison of standardized photographs and photographs taken with no specific standardization, the Facial, Frontal, Nasal, Oral, Orbital, Lip and Auricular Indexes were effective for human identification. Moreover, these indexes, both in non-standard photographs provided by patients as in standardized photographs, were able to positively identify a person. ${ }^{9}$

It is essential for orthodontic diagnosis and treatment and facial surgery planning to analyze the physical characteristics of the human body, with emphasis on the craniofacial complex, for orthodontic studies including measurements of height, width and angulation of structures, while taking into consideration the influence of muscles and geometric configuration of the face.

Cephalometric analysis is of great importance both for diagnosis and planning of orthodontic treatment. It is also crucial for communication among professionals. Measures related to the growth direction of the mandible - such as the mandibular angle, facial angle, facial axis, facial depth, mandibular plane, mandibular arch height and anterior lower face - determine the Vert Index, which cephalometrically distinguishes three facial types. ${ }^{6,7}$

»Mesofacial (balanced facial growth).

» Brachyfacial (predominance of horizontal facial growth).

»Dolichofacial (predominance of vertical facial growth).

In a first contact with the patient, some facial features can be observed only visually, such as asymmetries and facial type, but in a qualitative way. On this occasion, the most significant features should be noted, since through them we can see the facial growth trends, ${ }^{10}$ and through this preliminary diagnosis, determine what additional exams will be needed for a more accurate diagnosis. Once this records are analyzed and with the initial notes in hand, the final diagnosis and outline of orthodontic planning can be performed. 
One of our first impressions of patients' face shall give us the impression that they either have a long, medium or short face, and to confirm it, there are several analysis methods such as direct measurement on the face of patients or in photographs of the proportions between facial height and width, and the radiographic evaluation of craniofacial structures.

Determining the facial type is extremely important for orthodontic diagnosis and planning, since the muscular and skeletal configuration of each facial types responds differently to the orthodontic treatment, influencing either positively or negatively the final treatment results.

In orthodontics, the use of anthropometric measurements in the diagnosis has been gradually replaced, since it was presumed that the determination of facial types by means of anthropometric and cephalometric methods was equal. We currently use more frequently radiographic methods, which maintain a direct relationship with the craniofacial growth.

But, more than just a base for our planning on the direction of patient growth, we should also observe the craniofacial features in a comprehensive way, using indexes and anthropometric measurements, ${ }^{10}$ allowing for a proper evaluation of both qualitative and quantitative facial asymmetry and proportion, ${ }^{11}$ providing a more complete analysis of our patient.

In order to encourage the use of anthropometric analysis in orthodontic diagnosis, as well as to illustrate a specific situation for the application of one of its indexes, this study found a correlation between the determination of facial analysis through photographs and measurements by cephalometry.

\section{MATERIAL AND METHODS}

The sample consisted of 64 Brazilian individuals, 50 females and 14 males, Caucasians, aged between 18 and 38 years (mean age of 27 years and 9 months), who agreed to participate in this research and signed an informed consent about the nature of these studies. This study was approved by the São Paulo University Ethical Committee (approval number 131/06).

We chose Ricketts' Vert Index for the determination of cephalometric facial type, performed on lateral cephalometric radiographs, digitized by a specific scanner for radiographic films and measured with
Radiocef Studio 2 software (Radio Memory Ltda, Belo Horizonte, Brazil) (Fig 2).

The cephalometric measurements used to determine Vert Index were:

1. Facial Axis (FA): Angle between the lines BasionNasion and Gnation-Pterygoid.

2. Facial Depth (FD): Angle formed by lines NasionPogonion and Porion-Orbitale.

3. Lower Anterior Facial Height (LAFH): Angle formed by lines ANS-Xi and Xi-MP.

4. Mandibular Plane (MP): Angle formed by lines Porion-Orbitale and Gonial-Menton.

5. Mandibular Arch (MA): Angle formed by lines Dc-Xi and Xi-MP.

The facial type determined by the Vert Index in adults is given by the following equation, described by Gregoret: ${ }^{12}$

$\{[($ FA-90) $/ 3]+[($ FD-90) $/ 3]+[(24,5-\mathrm{MP}) / 4]+[(47-\mathrm{LAFH}) / 4)+[(\mathrm{MA}-28,5) / 4]\} / 5$

And follow the reference bellow:

» Brachyfacial: greater than +0.5 .

» Mesofacial: between -0.49 and +0.49 .

»Dolichofacial: smaller than -0.5.

The determination of the facial type by the $\mathrm{Fa}$ cial Index in facial photographs was made with the subjects facing forward, in standardized photos taken with individuals in their Natural Head Position (where the subject are positioned with a straight back and their arms resting along the trunk and looking at a fixed point in the center of the lens. When the operator observed a tilt of the head, this was corrected ${ }^{13}$ ), digitized and also measured with the program Radiocef Studio 2 (Fig 3).

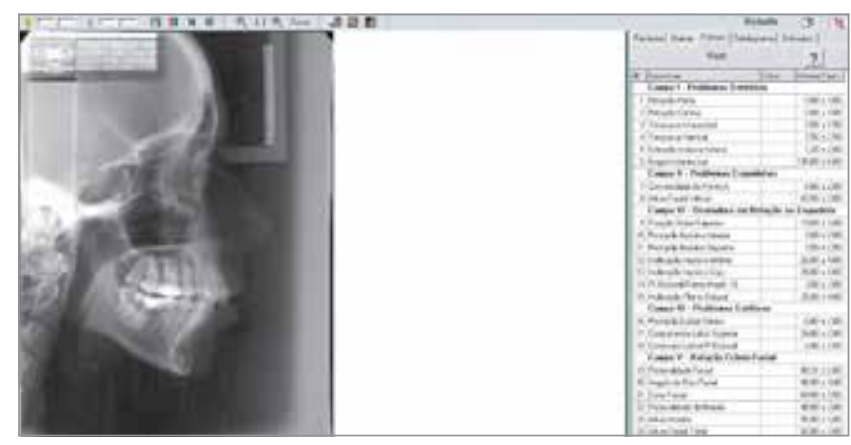

Figure 2 - Lateral cephalometric radiograph being analyzed in Radiocef Studio 2 software (configuration: Ricketts cephalometric analysis). 
The distances measured for determining the Facial Index were:

1) Anterior facial height ( $\mathrm{N}^{\prime}-\mathrm{Me}$ '): Distance between the points nasion and chin in soft tissue.

2) Facial width (Zid'- Zie'): Distance between left and right Zigium points in soft tissue corresponding to the lateral portion of the zygomatic process.

The facial type determined by the Facial Index is calculated as follows:

N' - Me' x 100 / Zid' - Zie'

According to the following reference: ${ }^{9}$

» Brachyfacial: smaller than 80.0 to $84.9 \%$.

» Mesofacial: 85.0 to $89.9 \%$.

» Dolichofacial: 90.0 to $95 \%$ or greater.

After verifying the percentages of occurrences for each facial type by the photometric method and by Vert Index, comparisons among the groups were performed using the Kruskal-Wallis test (done in the free statistical software Past). The level of significance in this study was $5 \%$. This test is designed to compare two or more independent samples in relation to a measurement of interest. Moreover, it is a nonparametric test, namely, not based on the mean and standard deviation, but in positions of the individuals in the sample. We opted for a non-parametric test because two groups showed a small number of observations to perform parametric tests.

The Kappa agreement index, which is also a nonparametric test, was used to check the level of agreement between the determinations of facial types by the two methods and followed the interpretation described next: If the range of agreement is lower than $40 \%$, the result is considered weak; if the value ranges between $40 \%$ and $75 \%$ of agreement, the result is considered reasonable to good; and if it exceeds $75 \%$, the correlation is high.

\section{RESULTS}

After statistical analysis of collected data, we obtained the results shown in Table 1. In Figure 4, we can observe the correlation between facial type determination by the photometric (A) and the cephalometric (B) methods.

With these results we can conclude that with a Kappa index of $76.5 \%$ (high level of agreement), cephalometric and photometric methods for determining facial types are equivalent.

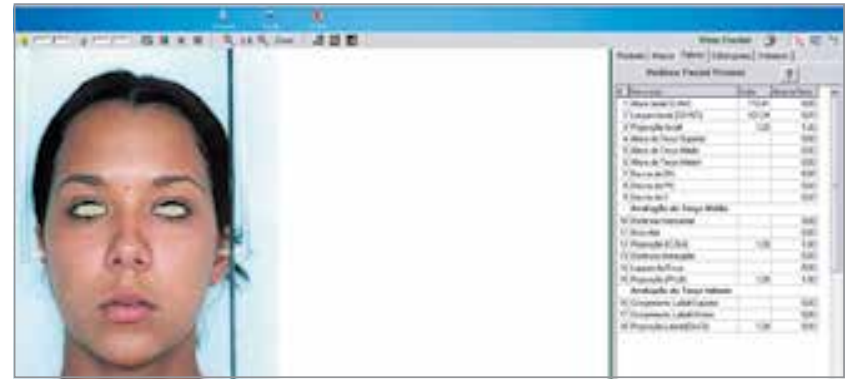

Figure 3 - Frontal photograph of a patient inserted into the Radiocef Studio 2 program (Facial Analysis configuration).

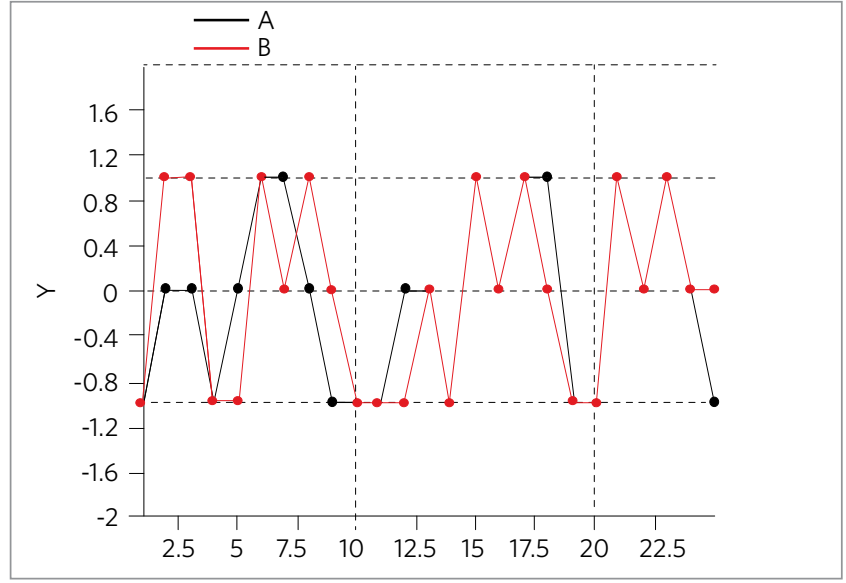

Figure 4 - Correlation between facial type determination by the photometric (A) and cephalometric (B) methods.

Table 1 - Comparison of facial type determination by anthropometric and Vert Index methods.

\begin{tabular}{|c|c|c|c|c|c|c|c|c|c|}
\hline \multirow{3}{*}{$\begin{array}{c}\text { Anthropometric } \\
\text { facial type }\end{array}$} & \multicolumn{9}{|c|}{ Ricketts facial type (Vert Index) } \\
\hline & \multicolumn{2}{|c|}{ Dolichofacial } & \multicolumn{2}{|c|}{ Mesofacial } & \multicolumn{2}{|c|}{ Brachyfacial } & \multicolumn{2}{|c|}{ Total } & \multirow{2}{*}{ Kappa } \\
\hline & $\mathbf{n}$ & $\%$ & $\mathrm{n}$ & $\%$ & n & $\%$ & $\mathbf{n}$ & $\%$ & \\
\hline Dolichofacial & 19 & 29.7 & 4 & 6.3 & 0 & 0.0 & 23 & 35.9 & \multirow{4}{*}{0.765} \\
\hline Mesofacial & 3 & 4.7 & 18 & 28.1 & 0 & 0.0 & 21 & 32.8 & \\
\hline Brachyfacial & 0 & 0.0 & 3 & 4.7 & 17 & 26.6 & 20 & 31.3 & \\
\hline Total & 22 & 34.4 & 25 & 39.1 & 17 & 26.6 & 64 & 100 & \\
\hline
\end{tabular}




\section{DISCUSSION}

The evaluation of the facial features are essential for carrying out a good orthodontic diagnosis, since the positioning of the bones and teeth certainly influence the appearance of soft tissues. ${ }^{1,2,6,7,10}$

As facial esthetics is one of the goals to be achieved at the end of orthodontic treatment, a good facial analysis, both qualitative ${ }^{1,2,4}$ and quantitative $^{10,11}$ must be observed when defining treatment plan.

Historically, orthodontic studies have been directed to evaluate the radiographic characteristics of craniofacial hard tissues and found scientific evidences on how these characteristics could influence the positioning of the soft tissues and its influences on facial esthetics ${ }^{6,7}$ Among the cephalometric assessments, there is the determination of the facial type, which is crucial for orthodontic planning. One way to determine the facial type of individuals through cephalometric analysis is the calculation of the Vert Index. ${ }^{6,7}$

Another method to determine the facial type is calculating the photometric Facial Index., ${ }^{5,-11}$ The photometry is a tool of anthropology where we can quantify the tangible characteristics of individuals through photographs.

The advantage of using oriented facial photographs in orthodontic studies is that, apart from the initial diagnostic studies, one can compare the same individual at different times of treatment or of his/her growth, and to compare different individuals and find similar characteristics between them, qualifying these individuals as a unique group., ${ }^{1,2,11}$

Since we found hard tissues influencing the positioning of soft tissues, we are able to deduce from this result that the facial soft tissues also can mask bone characteristics. ${ }^{10}$

The percentage of differences found on the determination of facial types using cephalometric and photographic analysis is supposedly due to the fact that there are cephalometric studies of bone structures in profile views, while in photographs, we evaluate individuals soft tissues in frontal view.

Based on the aforementioned, it can be concluded that it is important for diagnosis to evaluate both cephalometric and photometric analyses.

\section{CONCLUSIONS}

In this study, we observed that the facial type determination by the photometric method (Facial Index) showed to be reliable when compared to cephalometry (assessed by the Vert Index). However, the facial photometric analysis should be adjuvant, or supplemental, and not substitute for the cephalometric method, since, especially in cases where the values of Vert are borderline between two facial types, the soft tissues can mask the bone characteristics.

These results support the current trend to make a morphological analysis using facial photographs in orthodontics and facial surgery studies, as an essential ally to obtain accurate diagnosis and satisfactory results.

Another available possibility is to use facial photographs, standardized for determination of the facial type, in the selection of scientific studies samples by means of a less invasive method for the patient. This way an extra dose of radiation to will not be needed to determine whether or not the subject is eligible to participate in a study involving data concerning different facial types.

\section{REFERENCES}

1. Angle EH Classification of malocclusion. Dent Cosmos. 1899;41:248-64.

2. Angle EH. Treatment of malocclusion of the teeth: Angles System. Philadelphia (PA: S.S. White Dental; 1907.

3. Hohenstatt P. Masters of Italian Art - Leonardo da Vinci. Könemann: Verlagsgesellschft; 1998

4. Herzberg BL. Facial esthetic in relation to orthodontic treatment. Angle Orthod. 1952;22(1):3-22

5. Montangu A. A handbook of anthropometry. Springfield: Thomas Publisher III; 1960.

6. Ricketts RM. A foundation for cephalometric communication. Am J Orthod. 1960;46(5):330-57.

7. Ricketts RM. Cephalometric synthesis. Am J Dentofacial Orthod. 1960;46(9):647-73.

8. Farkas LG, Bryson W, Klotz J. Is photogrammetry of the face reliable? Plast Reconstr Surg. 1980;66(3):346-55

9. Daruge E, Zallaf CF. A biometria aplicada na identificação. RGO. 1985;33(2):153-55

10. Jacobson A. Planning for orthognathic surgery - art or science? Int J Adult Orthodon Orthognath Surg. 1990;5(4):217-24.

11. Martins LF. Análise fotométrica em norma frontal, de adultos, brasileiros, leucodermas, não tratados ortodonticamente, classificados pela estética facial [Dissertação]. São Bernardo do Campo (SP): UMESP, Faculdade de Odontologia; 2001

12. Gregoret J. Ortodontia e cirurgia ortognática. São Paulo (SP): Ed. Santos; 1999

13. Rino Neto J, Freire-Maia BAV, Paiva JB. Método de registro de posição natural da cabeça para obtenção da radiografia cefalométrica lateral - Considerações e importância do método no diagnóstico ortodôntico-cirúrgico. Dental Press. 2003;8(3):67-71. 